\title{
Plasma Lipoprotein(a) Levels and Expression of the Apolipoprotein(a) Gene are Dependent on the Nucleotide Polymorphisms in Its 5'-Flanking Region
}

\author{
Koji Suzuki, ${ }^{\star}$ Masaru Kuriyama, ${ }^{\ddagger}$ Tetsuo Saito, ${ }^{*}$ and Akitada Ichinose ${ }^{\star}$ \\ *Department of Molecular Pathological Biochemistry, Yamagata University School of Medicine, 2-2-2 Iida-Nishi, Yamagata, 990-23 \\ Japan; and ${ }^{\ddagger}$ Department of Internal Medicine III, Kagoshima University School of Medicine, Kagoshima, 890 Japan
}

\begin{abstract}
The apolipoprotein(a) (apo[a]) gene encodes a protein component of lipoprotein(a) [Lp(a)] whose plasma levels vary widely among individuals. Hyper-Lp(a)-emia constitutes a risk factor for thromboembolic disease. We previously subclassified the apo(a) gene into four allelic types (A-D) by polymorphisms in the $5^{\prime}$-flanking region. To elucidate whether these polymorphisms affect the expression of apo(a), we measured plasma Lp(a) concentrations in vivo by ELISA and examined expression of the gene by an in vitro assay using its $5^{\prime}$-flanking region. Homozygotes of type $\mathrm{C}$ had significantly higher $L p(a)$ levels than those of type $D$. The relative expression of type $\mathbf{C}$ was also about three times higher than that of type $D$, which was consistent with the in vivo results. Deletion analysis revealed that the substitution of $\mathrm{C}$ by $T(+93)$ led to negative regulation in expression of the gene, while the change of $\mathrm{G}$ to $\mathrm{A}(+121)$ led to positive regulation. These results indicate that the polymorphisms in the $5^{\prime}$-flanking region of the apo(a) gene affect the efficiency of its expression and, in part, play a role in regulating plasma Lp(a) levels. (J. Clin. Invest. 1997. 99:1361-1366.) Key words: atherosclerosis - myocardial infarction - cerebral infarction $\bullet 5^{\prime}$-allele $\bullet$ gene regulation
\end{abstract}

\section{Introduction}

Apolipoprotein(a) [apo(a)] is a high-molecular-weight glycoprotein, which is connected to apolipoprotein B-100 in lipoprotein(a) $(\mathrm{Lp}[\mathrm{a}])^{1}(1-4)$. Apo(a) shares homologous domains with plasminogen, including a signal peptide, variable repetitive domains of plasminogen kringle 4 (K4), a single plasminogen kringle 5, and a (pseudo)serine protease domain (5). Lp(a)

This paper was presented in part at the XIIth ICF meeting in Leuven, Belgium, September 1994 and at the 37th ASH meeting in Seattle, WA, December 1995.

Address correspondence to Akitada Ichinose, M.D., Ph.D., Department of Molecular Pathological Biochemistry, Yamagata University School of Medicine, 2-2-2 Iida-Nishi, Yamagata, 990-23 Japan. Phone: 81-236-28-5275; FAX: 81-236-28-5280; E-mail: aichinos@ med.id.yamagata-u.ac.jp

Received for publication 28 August 1996 and accepted in revised form 19 December 1996.

1. Abbreviations used in this paper: $\mathrm{Lp}(\mathrm{a})$, lipoprotein(a); K4, kringle 4; CAT, chloramphenicol acetyltransferase.

J. Clin. Invest.

(C) The American Society for Clinical Investigation, Inc.

0021-9738/97/03/1361/06 \$2.00

Volume 99, Number 6, March 1997, 1361-1366 acts as an anti-fibrinolytic factor in that it competes with plasminogen in the fibrin-binding (6-8), resulting in the inhibition of clot lysis $(7,9)$. Concentrations of $\mathrm{Lp}(\mathrm{a})$ in plasma vary among individuals from 0 to more than $200 \mathrm{mg} / \mathrm{dl}$ over a range of 1,000 -fold $(2,3)$. A population with a plasma $\mathrm{Lp}(\mathrm{a})$ level higher than $25-30 \mathrm{mg} / \mathrm{dl}$ has a higher incidence of acute myocardial infarction and cerebral infarction $(2-4,10,11)$.

The apo(a) locus contributes to greater than $90 \%$ of the variation in plasma $\mathrm{Lp}(\mathrm{a})$ concentrations and the number of $\mathrm{K} 4$ repeats in the apo(a) gene accounts for $\sim 70 \%$ of the variation (12, 13). Although the plasma Lp(a) concentration roughly correlates with the size and number of $\mathrm{K} 4$ repeats of apo(a) $(14,15)$, a significant variation in the $\mathrm{Lp}(\mathrm{a})$ level exists among individuals having the same isoform $(16,17)$. Several lines of evidence indicate that the plasma concentration of $\mathrm{Lp}(\mathrm{a})$ is determined by the rate of its synthesis, and not by the rate of catabolism (18-20); the catabolic rates of $\mathrm{Lp}(\mathrm{a})$ isoforms are not different regardless of the apo(a) size. Thus the genetic variation of the $\mathrm{Lp}(\mathrm{a})$ production rate in each apo(a) isoform may be caused by a difference in the apo(a) gene transcription, protein translation, or its secretion, etc. In a cynomolgus monkey model, plasma Lp(a) levels correlated with hepatic mRNA abundance (21).

In our previous studies $(22,23)$, nucleotide sequence analysis of the apo(a) gene revealed the presence of polymorphisms in its $5^{\prime}$-flanking region: $\mathrm{G} / \mathrm{A}$ at the positions $-773, \mathrm{C} / \mathrm{T}$ at +93 , and G/A at +121 , relative to the transcription start site (24). Since the nucleotide substitutions can be distinguished by the presence or absence of restriction sites for TaqI, MaeII, and HhaI endonucleases, respectively, the apo(a) alleles among individuals are classified by restriction digestion analysis into four types (23).

The differences in the nucleotide sequence of the 5 '-regulatory region may lead to differential transcriptional and/or translational efficiency, which in turn result in a wide variety of plasma Lp(a) levels, not only among individuals but also between ethnic groups $(2,25)$. In the present study, this hypothesis was tested in vivo by measuring plasma $\mathrm{Lp}(\mathrm{a})$ levels and in vitro by the chloramphenicol acetyltransferase (CAT) assay, when each of the four types of $5^{\prime}$-alleles was inserted into a promoterless CAT vector and their expression efficiency was compared directly.

\section{Methods}

Venous blood was drawn after informed consent had been obtained from normal individuals, patients with cerebral infarction, and their family members. A Tint Elize Lp(a) immunoassay kit was purchased from Biopool AB (Sweden). Genomic DNA samples were extracted from the leukocytes. HepG2, a human hepatocarcinoma cell line, was obtained from the Japanese Cancer Research Resources Bank (Tokyo). Reporter vectors, pCAT-Basic, -Enhancer, -Control, and pSV$\beta$-Galactosidase Control were purchased from Promega (Madison, WI). 
ELISA for plasma Lp (a) levels. Plasma Lp(a) concentrations were measured by an ELISA kit following the manufacturer's instructions. 96-well ELISA plates (Corning, NY) were first coated with an antiapo(a) monoclonal antibody at $4^{\circ} \mathrm{C}$ overnight before plasma samples were incubated. The wells were then incubated with an anti-apo(a) polyclonal antibody, peroxidase-conjugated rabbit anti-mouse immunoglobulin, and a substrate solution. Standard Lp(a) supplied by the manufacturer was used to estimate its concentrations in test samples.

Determination of apo(a) size. Apo(a) isoform size was determined by agarose/SDS-PAGE of plasma and subsequent Western blotting as described by Perombelon et al. (17). Delipidated and lyophilized samples from 8-100 $\mu \mathrm{l}$ of plasma were dissolved in $100 \mu \mathrm{l}$ of sample buffer (45 mM Tris- $\mathrm{HCl} \mathrm{pH} 6.8$, containing 5\% SDS, 10\% Glycerol, $0.015 \%$ bromophenol blue, $10 \% \beta$-mercaptoethanol) at $100^{\circ} \mathrm{C}$ for 4 min. The samples were run through $3 \%$ polyacrylamide gel containing $0.5 \%$ agarose. Proteins were transferred to nitrocellurose membranes and the bands of apo(a) were detected by employing a mouse anti-human Lp(a) antibody (Terumo, Tokyo, Japan). Apparent molecular weights of isoforms were estimated by Ferguson plots employing crosslinked phosphorylase $b$ as high molecular weight markers (Sigma Chemical Co., St. Louis, MO). Statistical analysis was performed using the StatView program (Abacus Concepts, Inc., Berkeley, CA).

Construction of CAT vectors. The promoter region of the apo(a) gene, a 1164-bp fragment extending from positions -1017 to +147 relative to the start site of transcription $(24,26)$, was prepared by PCR (polymerase chain reaction) using human genomic DNA as a template. Oligonucleotide primers were designed from the genomic sequence of apo(a) $(22,27)$, and flanked either by a synthetic PstI or XbaI restriction site at the $5^{\prime}$ ends: pair 1 (for amplification of types A, B, and D), 5'-side, 5'-CCTCCTGCAGTGCTGGGATTACAGAGTTGA-3' and 3'-side, 5'-ATGTCTAGATTTGGGACTGGCCAGCAGTGC-3'; pair 2 (for amplification of type C), 5'-side, $5^{\prime}$ CCTCCTGCAGTGCTGGGATTACAGAGTTGA-3' and $3^{\prime}$-side, 5'-ATGTCTAGATTTGGGACTGGCCAGCAGTGT-3' (PstI and $\mathrm{XbaI}$ sites underlined). PCR was carried out in a $50 \mu \mathrm{l}$ reaction mixture as described (28) using 2.5 units of Thermus aquaticus DNA polymerase (Taq polymerase; StrataGene, La Jolla, CA). Genomic DNAs were subjected to 30 cycles of amplification by heating at $94^{\circ} \mathrm{C}$ for $1 \mathrm{~min}$ to denature the DNA, cooling to $68^{\circ} \mathrm{C}$ for $1 \mathrm{~min}$ to anneal primers, and incubating at $72^{\circ} \mathrm{C}$ for $1 \mathrm{~min}$ to extend the annealed primers. The PCR products were then digested with PstI and XbaI endonucleases, and ligated into a promoterless pCAT-Enhancer vector between unique PstI and $\mathrm{XbaI}$ sites. The constructed plasmids were designated as pCAT-A, B, C, and D (Fig. $1 A$, top four), corresponding to each of the four $5^{\prime}$-alleles (23).

A $5^{\prime}$-deletion mutant of each subtype containing a genomic fragment of apo(a) extending from -304 to +147 was constructed from either pCAT-A, B, C, or D by digestion with HindIII endonuclease (to cleave the HindIII site within the insert) and with XbaI endonuclease (to cleave the XbaI site in the vector). The DNA fragments were subcloned into a HindIII/XbaI-digested pCAT-Enhancer vector. The constructed plasmids containing two polymorphic sites at positions +93 and +121 were designated as pCAT $-\Delta \mathrm{A}, \Delta \mathrm{C}$, and $\Delta \mathrm{D}$ (Fig. $1 A$, middle three; pCAT- $\Delta \mathrm{A}$ and pCAT- $\Delta \mathrm{B}$ are identical). In addition, $3^{\prime}$-deletion mutants containing genomic fragments extending from -304 to +120 were constructed from pCAT- $\Delta \mathrm{A}, \Delta \mathrm{C}$, and $\Delta \mathrm{D}$ by digestion with Bsp1286I endonuclease (to cut the site within the insert at position +120). The DNA fragments were then isolated from agarose gels, blunted by T4 DNA polymerase (Takara, Otsu, Japan), and digested with HindIII endonuclease. The resulting HindIII/ blunt-end fragments of the apo(a) gene were cloned into the HindIII/ XbaI-digested pCAT-Enhancer vector in which the XbaI cohesive terminus was changed to a blunt end by T4 DNA polymerase. These constructed plasmids contained only one polymorphic site at position +93 and were designated as pCAT- $3^{\prime} \Delta \mathrm{A}$ and $3^{\prime} \Delta \mathrm{D}$ (Fig. $1 \mathrm{~A}$, bottom two; $\mathrm{pCAT}-3^{\prime} \Delta \mathrm{A}$ and $\mathrm{pCAT}-3^{\prime} \Delta \mathrm{C}$ are identical). The sequence of the inserts in all vectors was confirmed by the dideoxy chain termination method (29) using a Sequenase kit (United States Biochemical, Cleveland, $\mathrm{OH})$ and oligonucleotide primers prepared in the previous studies $(22,27)$.

Cell culture and transient transfection. HepG2 cells were grown in 100-mm dishes in Dulbecco's modified Eagle's medium (DME; Nikken Biomedical Laboratory, Kyoto, Japan) containing 10\% fetal bovine

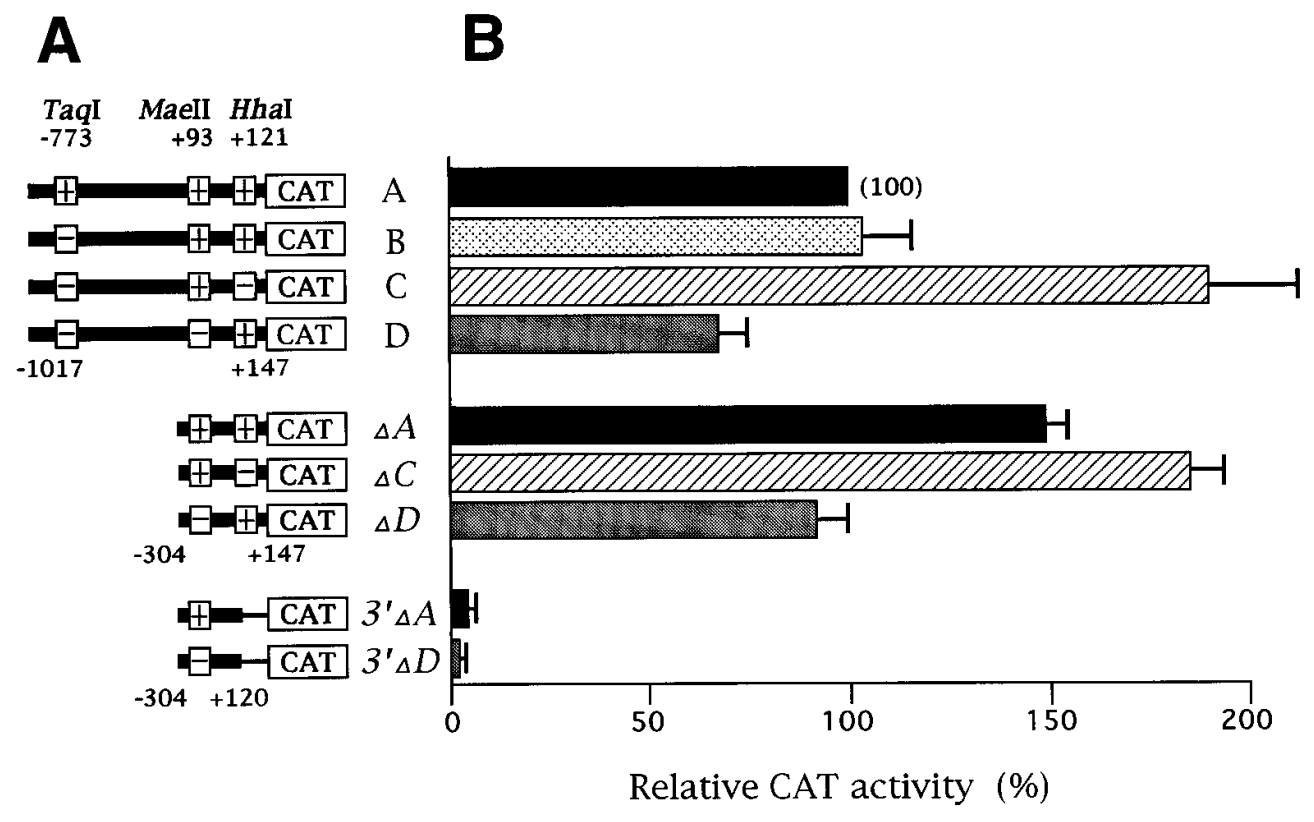

Figure 1. (A) Construction of plasmids carrying $5^{\prime}$-alleles. Four types $(A, B, C$, and $D$; top four) of the $5^{\prime}$-flanking region of the apo(a) gene (a 1164-bp fragment) were prepared by PCR with allele-specific primers. These fragments were inserted into a promoterless pCATEnhancer vector. 5'-deletion mutants $(\Delta A, \Delta C$, and $\Delta D$; middle three) were constructed from each subtype of the pCAT plasmids. $3^{\prime}$ deletion mutants $\left(3^{\prime} \Delta A\right.$ and $3^{\prime} \Delta D$, bottom two ) were also constructed from the $5^{\prime}$ deletion mutants. (B) Expression activity of four 5 -alleles of the apo(a) gene and their deletion mutants. HepG2 cells were transfected with test plasmids together with a pSV- $\beta$-Galactosidase vector as a control for transfection efficiency. CAT activity was normalized to $\beta$-galactosidase activity and was presented relative to that of type A $(100 \%)$. 
serum (SEBAK GmbH, Germany), $50 \mu \mathrm{g} / \mathrm{ml}$ penicillin, $50 \mu \mathrm{g} / \mathrm{ml}$ streptomycin, and $100 \mu \mathrm{g} / \mathrm{ml}$ neomycin (PSN Antibiotic Mixture; GIBCO BRL, Gaithersburg, MD). For transient transfection, plasmids were prepared by double ultracentrifugation using cesium chloride density gradient. 2-3 $\times 10^{6}$ HepG2 cells were transfected by the calcium phosphate method (30) with $10 \mu \mathrm{g}$ of test plasmids carrying a reporter gene and $5 \mu \mathrm{g}$ of $\mathrm{pSV}-\beta$-Galactosidase plasmid to monitor the efficiency of transfection. Both pCAT-Basic and -Control vectors were also used as negative and positive controls, respectively, for the expression experiments. The cells were incubated for $5 \mathrm{~h}$ and shocked with $15 \%$ (vol/vol) glycerol in Hepes-buffer saline for $2 \mathrm{~min}$. After being cultured for $48 \mathrm{~h}$, the cells were harvested for analysis of chloramphenicol acetyltransferase (CAT) and $\beta$-galactosidase expression.

These experiments were also carried out using a human cervical carcinoma (cell line), HeLa cells, and baby hamster kidney (BHK) cells.

$C A T$ and $\beta$-galactosidase assays. To evaluate the expression of reporter plasmids, cells were removed from culture plates with $0.25 \%$ trypsin and $1 \mathrm{mM}$ EDTA, washed with phosphate buffered saline (PBS) twice, and resuspended in $200 \mu \mathrm{l}$ of $0.25 \mathrm{M}$ Tris- $\mathrm{HCl}, \mathrm{pH} 7.8$. The cells were then lysed by three freeze/thaw cycles and centrifuged, and $50 \mu \mathrm{l}$ of supernatant was then examined for CAT activity by a standard method (31). To evaluate the expression of the pSV- $\beta$-Galactosidase Control vector, $30 \mu \mathrm{l}$ of the supernatant of cell lysates was mixed with $201 \mu \mathrm{l}$ of $0.1 \mathrm{M}$ sodium phosphate buffer ( $\mathrm{pH} 7.8$ ), $66 \mu \mathrm{l}$ of $o$-nitrophenyl $\beta$-D-galactopyranoside (ONPG; Sigma Chemical Co.), and $3 \mu \mathrm{l}$ of $0.1 \mathrm{M} \mathrm{MgCl}_{2}, 4.5 \mathrm{M} \beta$-mercaptoethanol. Samples were incubated at $37^{\circ} \mathrm{C}$ for $30 \mathrm{~min}$ and reaction was then stopped with $500 \mu \mathrm{l}$ of $\mathrm{Na}_{2} \mathrm{CO}_{3}$. $\beta$-galactosidase activity was measured by absorp-

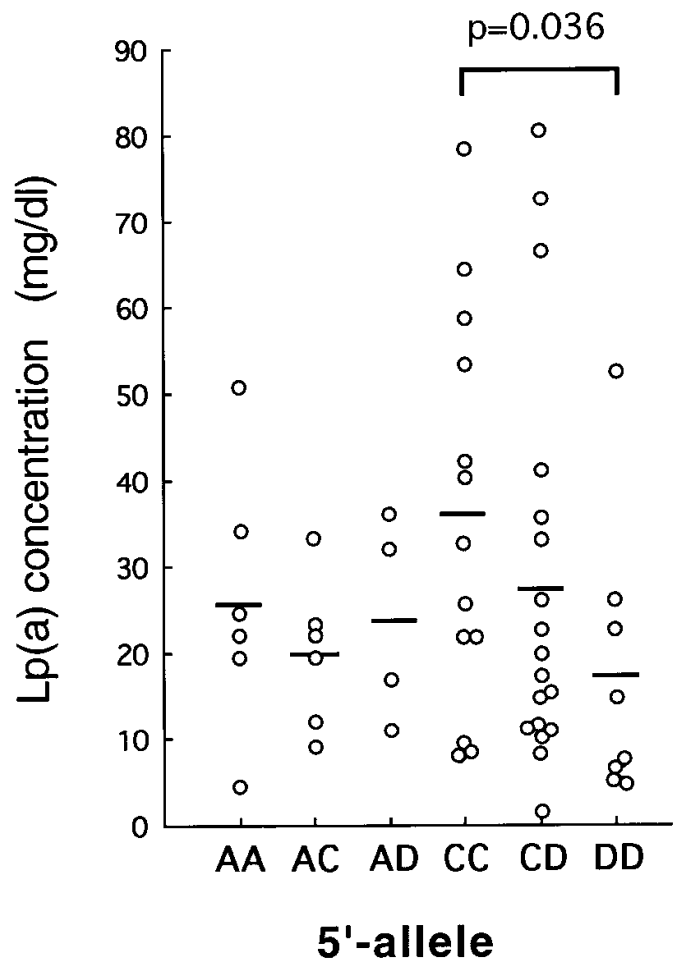

Figure 2. 5'-alleles and $\mathrm{Lp}(\mathrm{a})$ levels. The genotype of the $5^{\prime}$-allele was determined by genetic diagnosis and classified into four types (23), e.g., CC stands for homozygotes of type C and CD for heterozygotes of types $\mathrm{C}$ and $\mathrm{D}$. Concentrations of plasma $\mathrm{Lp}(\mathrm{a})$ were measured by ELISA as described in Methods. Samples from patients with cerebral infarction and those of their family members are indicated by open circles, respectively. Wide bars indicate averages for individual groups. tion at $420 \mathrm{~nm}$ (32). CAT activities were normalized to $\beta$-galactosidase activity for each dish. Within each experiment CAT activity was determined in duplicate or triplicate dishes, and each plasmid was tested in three to five separate experiments; therefore results are expressed as the mean of 6-10 values.

\section{Results}

Relationship between 5'-alleles and plasma Lp (a) levels. To investigate whether or not the $5^{\prime}$-alleles of the apo(a) gene affect plasma $\mathrm{Lp}(\mathrm{a})$ levels, we measured plasma $\mathrm{Lp}(\mathrm{a})$ levels by ELISA in patients with cerebral infarction and their family members ( $n=55$, Fig. 2 ). Their $5^{\prime}$-alleles were determined in the previous study (23). Plasma Lp(a) levels were significantly higher $(P=0.036)$ in homozygotes $(n=13)$ of the type $\mathrm{C}$ allele than in those $(n=8)$ of the type D allele (means \pm SD; $35.8 \pm 22.8$ vs. $17.5 \pm 16.2 \mathrm{mg} / \mathrm{dl})$. The difference in $\mathrm{Lp}(\mathrm{a})$ levels between these two groups cannot be attributed to the size polymorphism in apo(a), due to the differences in the number of $\mathrm{K} 4$ repeats, since the averages of the molecular weights were essentially the same for both groups (CC 906 \pm 291 vs. DD $895 \pm 91 \mathrm{kD}, P=0.911)$. Plasma Lp(a) concentrations varied and weakly correlated inversely with apo(a) size within the same $5^{\prime}$-allele $(\mathrm{CC} r=-0.64$, DD $r=-0.50)$ as well as in the total for all groups $(r=-0.57)$ as shown in Fig. 3. Although differences in the averages of $\mathrm{Lp}(\mathrm{a})$ levels between other allelic groups were not significant, it was noteworthy that the average of heterozygotes of types $\mathrm{C}$ and $\mathrm{D}(n=18,27.8 \pm 23.4$ $\mathrm{mg} / \mathrm{dl}$ ) was between that of homozygotes of type $\mathrm{C}$ and that of type D. Accordingly, it is very likely that the wide variation within the same apo(a) isoform (size) is caused at least in part by the difference in the $5^{\prime}$-alleles. We therefore compared the promoter activity of the four types of $5^{\prime}$-allele, including types

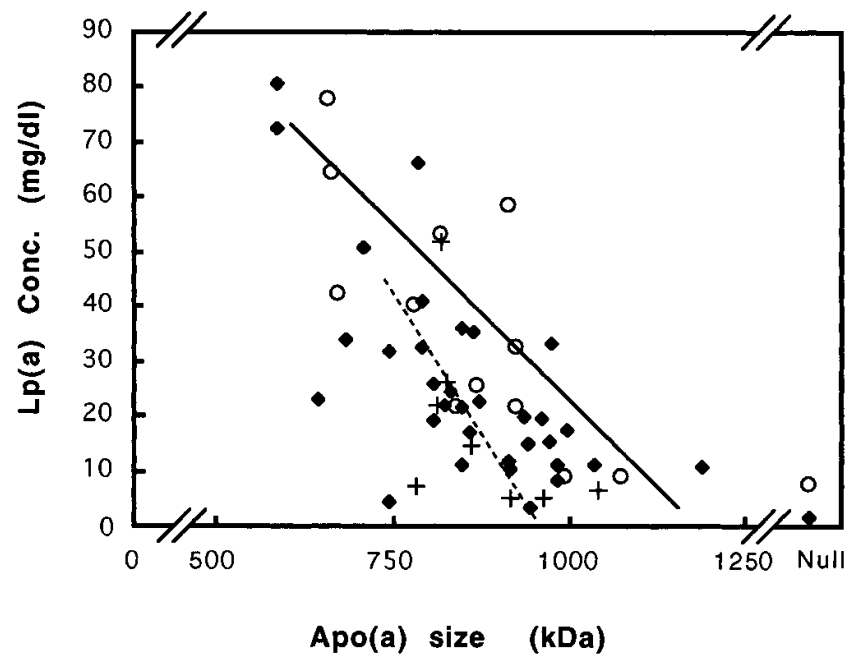

Figure 3. Relationship between $\mathrm{Lp}$ (a) concentration and apo(a) size. $\mathrm{Lp}$ (a) concentration and apo(a) size were determined by ELISA and Western blotting analysis, respectively, as described in the Methods and Materials section. An average of larger and smaller apo(a) isoforms of a given individual was plotted against his/her corresponding plasma Lp(a) concentration. Open circles represent CC homozygotes, plus marks indicate DD homozygotes, and closed diamonds depict the remaining genotypes. The solid and broken lines represent regression lines of best fit for the $\mathrm{CC}$ and DD groups, respectively. 
C and D, to test whether the difference in $\mathrm{Lp}(\mathrm{a})$ levels was attributable to the difference in apo(a) expression and in nucleotide sequence.

Expression efficiency of four 5'-alleles. To compare promoter activity of the four $5^{\prime}$-alleles in vitro, a CAT reporter gene assay was used. Each DNA fragment (1.2-kb) carrying one of four 5 '-alleles was prepared by PCR and inserted into the pCAT-Enhancer vector upstream of the CAT gene (Fig. $1 \mathrm{~A}$, top). A test plasmid and $\beta$-Galactosidase Control plasmid were co-transfected into HepG 2 cells, and examined for CAT and $\beta$-galactosidase expression. The HepG 2 cells, in which the apo(a) mRNA was detected (5), have been exclusively used for the CAT assay of the apo(a) gene $(24,26,33,34)$. CAT activity was normalized to $\beta$-galactosidase activity and was presented as a percentage of the type A allele (100\%). The relative promoter activity was $103 \pm 22.6 \%$ for type B, $191 \pm 39.5 \%$ for type $\mathrm{C}$, and $67 \pm 10.9 \%$ for type D (Fig. $1 \mathrm{~B}$, top). Thus, the relative expression efficiency of type $C$ was about three times higher than that of type D. These experiments were also carried out using HeLa cells, a human cervical carcinoma cell line, as well as baby hamster kidney (BHK) cells, but, in these cells, no CAT activity for the apo(a) gene was detected (data not shown). These results indicated that the apo(a) gene is specifically expressed in hepatic cells, which is consistent with the fact that its mRNA is most abundant in the liver $(5,21)$.

Effect of each polymorphic site on expression. To explore the effects of the three polymorphic sites on the regulation of apo(a) expression, we performed deletion analysis for each pCAT plasmid containing $5^{\prime}$-alleles. Three 5 '-deletion mutants carrying 451-bp genomic fragments from -304 to +147 contained two polymorphic sites at +93 and +121 (Fig. $1 A$, middle). Type $\Delta \mathrm{A}$ and type $\Delta \mathrm{B}$ were judged to be identical because the 5 '-portion (from -1017 to -305 including a polymorphism at -773 ) was absent in these deletion mutants. The CAT activity of type $\Delta \mathrm{A}$ was $150 \pm 5.9 \%$, type $\Delta \mathrm{C}$ was $181 \pm 12.4 \%$, and type $\Delta \mathrm{D}$ was $91 \pm 9.0 \%$ that of type A (Fig. $1 B$, middle).

Two $3^{\prime}$-deletion mutants $\left(3^{\prime} \Delta \mathrm{A}\right.$ and $\left.3^{\prime} \Delta \mathrm{D}\right)$, each carrying a genomic fragment of 424-bp from -304 to +120 , contained only one polymorphic site at +93 (Fig. $1 \mathrm{~A}$, bottom). The CAT activity of type $3^{\prime} \Delta \mathrm{A}$ was $3.8 \pm 0.30 \%$, and type $3^{\prime} \Delta \mathrm{D}$ was $2.1 \pm 0.47 \%$ that of the type A $(675 \pm 53$ vs. $242 \pm 54 \mathrm{cpm}$, Fig. $1 B$ ). Thus, one nucleotide substitution at +93 led to the difference in promoter activity, despite the fact that the deletion from +121 to +147 caused a great reduction in the activity of both mutants.

\section{Discussion}

Since plasma concentrations of $\mathrm{Lp}$ (a) vary widely among individuals, even among those having the same apo(a) isoform (16, 17), there must be a difference in the nucleotide sequence linked to the apo(a) locus other than the number of K4 repeats. We recently reported the presence of polymorphisms in the 5'-flanking region of the apo(a) gene (22). Additionally, genomic DNAs from normal individuals have been subclassified into four $5^{\prime}$-alleles by genetic diagnosis (23).

In this study, to explore the mechanisms of genetic control of plasma Lp(a) levels, we measured plasma Lp(a) concentrations in vivo by ELISA and examined the expression of its gene by an in vitro CAT assay. It was found that there was a clear relationship between $5^{\prime}$-alleles and plasma Lp(a) levels.
Lp(a) levels in homozygotes of the type $C$ allele were significantly higher (about two times) than in homozygotes of the type $\mathrm{D}$ allele, suggesting that at least some $5^{\prime}$-alleles are associated with different levels of plasma $\mathrm{Lp}(\mathrm{a})$.

The CAT assay revealed that the promoter activity of type $\mathrm{C}$ was higher than that of type $\mathrm{D}$, indicating that these in vitro results are consistent with the in vivo results as described above, and that the $5^{\prime}$-alleles have differences not only in their nucleotide sequences, but also in their promoter activity. Thus, other than the number of K4 repeats, the sequence variation at the apo(a) locus is associated with the genetic control of apo(a) expression and with $\mathrm{Lp}(\mathrm{a})$ concentrations.

Recently, another research group reported similar findings with regard to types $\mathrm{A}(+93 \mathrm{C}$ in reference 33$)$ and D (+93T in reference 33); however, their results are somewhat confusing in that they stated that type A (A1 in reference 24) was fivefold more active than type B (A2 in reference 24). Moreover, their study does not include deletion analysis of the polymorphic sites. It has also been reported by others that a difference in the number of tandem repeats ([TTTTA]n) located $1.3 \mathrm{~kb}$ upstream of the transcription initiation site of the apo(a) gene is not related to the transcriptional activity (34).

To define the effect of each polymorphism on apo(a) expression, $5^{\prime}$-deletion analysis of the four $5^{\prime}$-alleles was carried out (Fig. $1 \mathrm{~B}$ ). There is a difference of only a single nucleotide at position +121 (HhaI site) between types $\Delta \mathrm{A}$ and $\Delta \mathrm{C}$. The relative CAT activity of type $\Delta \mathrm{C}(\mathrm{HhaI}-)$ was about 1.2 -fold that of type $\Delta \mathrm{A}(\mathrm{HhaI}+)$ and that of type $\mathrm{C}$ was twofold that of type $\mathrm{A}$, while the activities of type $\mathrm{C}$ and type $\Delta \mathrm{C}$ were essentially the same. Thus, the difference in CAT activity between type $\mathrm{A}$ and type $\mathrm{C}$ may depend on the differential interaction between the HhaI site and a further upstream region(s). It is possible that the TaqI site at position -773 affects the function of the HhaI site in expression; the removed region between -1017 and -304 , including the TaqI site, may have a significant silencer function only in combination with the presence of the HhaI site at position +121 . However, it seems likely that the polymorphism at -773 would have a small effect, if any, since there is no significant difference in the CAT activity between types $\mathrm{A}$ and $\mathrm{B}$, which differ only in the single nucleotide at -773 .

Both 5'-deletion mutants $\Delta \mathrm{A}$ and $\Delta \mathrm{D}$ demonstrated higher CAT activity $(\sim 1.5$-fold $)$ than did their parent types, indicating that the removed fragment contains negative regulatory elements (silencers). Type $\Delta \mathrm{A}$ and type $\Delta \mathrm{D}$ differ in only one nucleotide at position +93 (the MaeII site). The relative CAT activity of type $\Delta \mathrm{D}$ (MaeII -) was about two-thirds that of type $\Delta \mathrm{A}(\mathrm{MaeII}+)$, which reflects the ratio of the activity of their respective parent types exactly. Therefore, the differential CAT activity would appear to depend at least in part on the MaeII site.

This conclusion was also confirmed by the results of $3^{\prime}$-deletion analysis, since CAT activity of type $3^{\prime} \Delta \mathrm{A}(\mathrm{MaeII}+)$ was about twofold that of $3^{\prime} \Delta \mathrm{D}$ (MaeII-). There was a marked reduction in the activity of both mutants. The removed fragment may have an essential sequence(s) for transcription as reported by Wade et al. (26). These results suggest that both polymorphisms (positions +93 and +121 ) affect the promoter activity of the four 5 -alleles. MaeII $(-)$ allele $(+93 \mathrm{~T})$ has lower activity when compared with MaeII $(+)$ allele $(+93 \mathrm{C})$, while HhaI $(-)$ allele $(+121 \mathrm{~A})$ exhibits higher activity when compared with HhaI $(+)$ allele $(+121 \mathrm{G})$ (Fig. 4). 


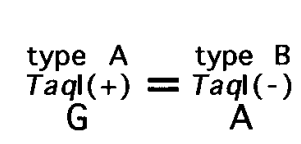

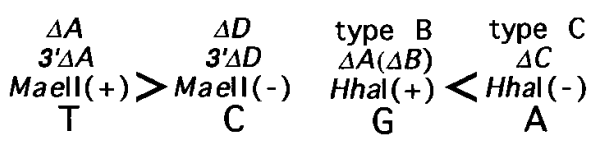

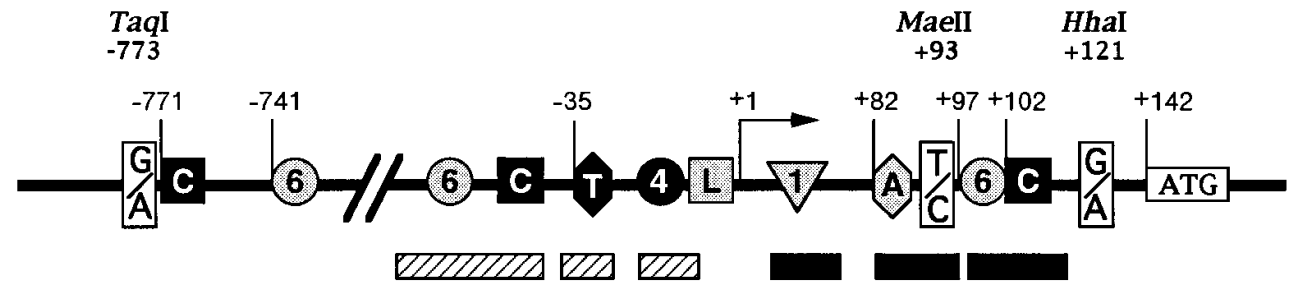

Figure 4. DNA-binding-protein sites around three polymorphic sites in the $5^{\prime}$-flanking region. The start site of transcription is indicated by an arrow and that of translation is indicated by ATG. Nucleotide positions are relative to the transcription start site. Polymorphisms at positions $-773,+93$, and +121 are boxed. Potential sites for the binding of regulatory proteins are shown by shaded circles (IL-6 responsive element), a closed circle (HNF-4), a shaded square

(LF-A1), closed squares (CEBP), a shaded triangle (HNF-1 $\alpha$ ), a shaded hexagon (AP-1), and a closed hexagon (TATA box), respectively. Actual protein-binding sites reported by Wade et al. (26) are indicated by hatched and closed bars; the latter have significant effects on apo(a) expression.

In the $5^{\prime}$-flanking region of the apo(a) gene, several major protein-binding sites were identified by DNase protection assays (26). The polymorphism at +93 is included within a protein-binding site containing an AP-1 site, and the polymorphism at +121 is located near a protein-binding site including a CEBP site and an IL-6-responsive element (Fig. 4). Both sites have been confirmed by site-directed mutagenesis to have significant effects on expression of the apo(a) gene (26). Therefore, the differential promoter activity of the four $5^{\prime}$-alleles may be caused by a gain and/or loss of binding sites for transcription factors as a result of these nucleotide substitutions. However, it was proposed that the polymorphism at position +93 reduced the efficiency of translation rather than transcription (33). This type of gene regulation was reported in several genes including that for the androgen receptor (35).

Thus, we have concluded in this study that the nucleotide polymorphism in the $5^{\prime}$-flanking region of the apo(a) gene ( $5^{\prime}$-allele) is one of the major factors which determine plasma $\mathrm{Lp}$ (a) levels. The apo(a) gene is highly polymorphic both in size and in sequence, which in turn leads to the wide variety of plasma $\mathrm{Lp}(\mathrm{a})$ levels seen among individuals. We recently reported that the ratio of the $5^{\prime}$-alleles of apo(a) differed between normal individuals and patients with myocardial infarction (23) in which elevated $\mathrm{Lp}(\mathrm{a})$ levels were found (36-38). The high $\mathrm{Lp}$ (a) levels observed in myocardial infarction can be explained in part by the fact that there are less individuals having type $\mathrm{D}$, which has low expression efficiency of the apo (a) gene. To elucidate the clinical significance of these nucleotide polymorphisms in the pathological roles of apo(a), further studies are required, e.g., determination of the relationships between the 5 -alleles, plasma concentrations of $\mathrm{Lp}(\mathrm{a})$, and the incidence of atherothrombotic disease.

As reported by other investigators $(16,17)$, the weak inverse correlation between plasma $\mathrm{Lp}(\mathrm{a})$ concentrations and apo(a) size was also observed in our study. However, Lp(a) levels varied even within the same $5^{\prime}$-allele having similar apo(a) isoforms (Fig. 3), suggesting that the apo(a) expression is also affected by non-genetic factors, e.g. cytokines and hormones, since $L p(a)$ levels change under various conditions (39, 40). Alternatively, other genetic elements other than the $5^{\prime}$-allele and the number of $\mathrm{K} 4$ repeats may play a role in the regulation of the apo(a) expression, although such elements are not known to date.

\section{Acknowledgments}

The authors thank Terumo Co. for providing the anti-apo(a) monoclonal antibody, Drs. T. Hashiguchi, S. Tsutsumi, T. Izumi, and N. Takabatake for their helpful discussion, and L. Boba for her help in the preparation of the manuscript.

This work was supported by research grants from Yamagata University, the Ministry of Education, Science and Culture, Japan (05454327), Yamagata Prefecture (Japan), the Japan Brain \& Nerve Foundation, Inamori Foundation (Japan), and the Mitsui Life Social Welfare Foundation (Japan).

\section{References}

1. Berg, K. 1963. A new serum type system in man-the Lp(a) system. Acta Pathol. Microbiol. Scand. 59:369-382.

2. Utermann, G. 1989. The mysteries of lipoprotein(a). Science (Wash.DC). 246:904-910.

3. Scanu, A.M., and G.M. Fless. 1990. Lipoprotein(a): heterogeneity and biological relevance. J. Clin. Invest. 85:1709-1715.

4. Miles, L.A., and E.F Plow. 1990. An interloper into the fibrinolytic system? Thromb. Haemost. 63:331-335.

5. McLean, J.W., J.E. Tomlinson, W.J. Kuang, D.L. Eaton, E.Y. Chen, G.M. Fless, A.M. Scanu, and R.M. Lawn. 1987. cDNA sequence of human apolipoprotein(a) is homologous to plasminogen. Nature (Lond.). 330:132-137.

6. Harpel, P.C., B.R. Gordon, and T.S. Parker. 1989. Plasmin catalyzes binding of lipoprotein(a) to immobilized fibrinogen and fibrin. Proc. Natl. Acad. Sci. USA. 86:3847-3851.

7. Loscalzo, J., M. Weinfeld, G.M. Fless, and A.M. Scanu. 1990. Lipoprotein(a), fibrin binding, and plasminogen activation. Arteriosclerosis. 10:240-245.

8. Rouy, D., M.L. Koschinsky, V. Fleury, J. Chapman, and E. Angles-Cano. 1992. Apolipoprotein(a) and plasminogen interactions with fibrin: a study with recombinant apolipoprotein(a) and isolated plasminogen fragments. Biochemistry. 31:6333-6339.

9. Edelberg, J.M., M. Gonzalez-Gronow, and S.V. Pizzo. 1989. Lipoprotein(a) inhibits streptokinase-mediated activation of human plasminogen. Biochemistry. 28:2370-2374.

10. Rhoads, G.G., G. Dahlen, K. Berg, N.E. Morton, and A.L. Dannenberg. 1986. Lp(a) lipoprotein as a risk factor for myocardial infarction. Am. J. Med. Assoc. 256:2540-2544.

11. Murai, A., T. Miyahara, N. Fujimoto, M. Matsuda, and M. Kameyama. 1986. Lp(a) lipoprotein as a risk factor for coronary heart disease and cerebral infarction. Atherosclerosis. 59:199-204.

12. Boerwinkle, E., H.J. Menzel, H.G. Kraft, and G. Utermann. 1989. Contribution of the quantitative $\mathrm{Lp}(\mathrm{a})$ lipoprotein trait. III. Contribution of $\mathrm{Lp}(\mathrm{a})$ glycoprotein phenotypes to normal lipid variation. Hum. Genet. 82:73-78.

13. Boerwinkle, E., C.C. Leffert, J. Lin, C. Lackner, G. Chiesa, and H.H. Hobbs. 1992. Apolipoprotein(a) gene accounts for greater than $90 \%$ of the variation in plasma lipoprotein(a) concentrations. J. Clin. Invest. 90:52-60.

14. Gavish, D., N. Azrolan, and J.L. Breslow. 1989. Plasma Lp(a) concentration is inversely correlated with the ratio of Kringle IV/Kringle V encoding domains in the apo(a) gene. J. Clin. Invest. 84:2021-2027.

15. Lackner, C., E. Boerwinkle, C.C. Leffert, T. Rahmig, and H.H. Hobbs. 
1991. Molecular basis of apolipoprotein(a) isoform size heterogeneity as revealed by pulsed-field gel electrophoresis. J. Clin. Invest. 87:2153-2161.

16. Kraft, H.G., S. Kochl, H.J. Menzel, C. Sandholzer, and G. Utermann. 1992. The apolipoprotein(a) gene: a transcribed hypervariable locus controlling plasma lipoprotein(a) concentration. Hum. Genet. 90:220-230.

17. Perombelon, Y.F., A.K. Soutar, and B.L. Knight. 1994. Variation in lipoprotein(a) concentration associated with different apolipoprotein(a) alleles. J. Clin. Invest. 93:1481-1492.

18. Krempeler, F., G.M. Kostner, K. Bolzano, and F. Sandhofer. 1980. Turnover of lipoprotein(a) in man. J. Clin. Invest. 65:1483-1490.

19. Rader, D.J., W. Cain, L.A. Zech, D. Usher, and H.B. Brewer. 1993. Variation in lipoprotein(a) concentrations among individuals with the same apolipoprotein(a) isoform is determined by the rate of lipoprotein(a) production. J. Clin. Invest. 91:443-447.

20. Rader, D.J., W. Cain, K. Ikewaki, G. Tally, L.A. Zech, D. Usher, and H.B. Brewer. 1994. The inverse association of plasma lipoprotein(a) concentrations with apolipoprotein(a) isoform size is not due to difference in Lp(a) catabolism but to differences in production rate. J. Clin. Invest. 93:2758-2763.

21. Azrolan, N., D. Gavish, and J.L. Breslow. 1991. Plasma lipoprotein(a) concentration is controlled by apolipoprotein(a) (apo(a)) protein size and the abundance of hepatic apo(a) mRNA in a cynomolgus monkey model. J. Biol. Chem. 266:13866-13872.

22. Ichinose, A. 1995. Characterization of the apolipoprotein(a) gene. Biochem. Biophys. Res. Commun. 209:365-371.

23. Ichinose, A., and M. Kuriyama 1995. Detection of polymorphisms in the 5 '-flanking region of the gene for apolipoprotein(a). Biochem. Biophys. Res. Commun. 209:372-378.

24. Wade, D.P., G.E. Lindahl, and R.M. Lawn. 1994. Apolipoprotein gene transcription is regulated by liver-enriched trans-acting factor Hepatocyte $\mathrm{Nu}$ -

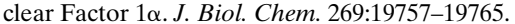

25. Gaw, A., E. Boerwinkle, J.C. Cohen, and H.H. Hobbs. 1994. Comparative analysis of the apo(a) gene, glycoprotein, and plasma concentration of Lp(a) in three ethnic groups. J. Clin. Invest. 93:2526-2534.

26. Wade, D.P., J.G. Clarke, G.E. Lindahl, A.C. Liu, B.R. Zysow, K. Meer, K. Schwartz, and R.M. Lawn. 1993. 5' control regions of the apolipoprotein(a) gene and members of the related plasminogen gene family. Proc. Natl. Acad. Sci. USA. 90:1369-1373.

27. Ichinose, A. 1992. Multiple members of plasminogen-apolipoprotein(a) gene family associated with thrombosis. Biochemistry. 31:3113-3118.

28. Saiki, R.K., D.H. Gelfand, S.J. Stoffel, R. Higuchi, G.T. Horn, K.B.
Mullis, and H.A. Erlich. 1988. Primer-directed enzymatic amplification of DNA with a thermostable DNA polymerase. Science (Wash. DC). 239:487-491.

29. Sanger, F., S. Nicklen, and A.R. Coulson. 1977. DNA sequencing with chain-termination inhibitors. Proc. Natl. Acad. Sci. USA. 74:5463-5467.

30. Sambrook, J., E.F. Fritsch, and T. Maniatis. 1989. Molecular Cloning: A Laboratory Manual, Cold Spring Harbor Laboratory Press, Plainview, NY.

31. Gorman, C.M., L.F. Moffat, and B.H. Howard. 1982. Recombinant genomes which express chloramphenicol acetyltransferase in mammalian cells Mol. Cell. Biol. 2:1044-1051.

32. Hall, C.V., P.E. Jacob, G.M. Ringold, and F. Lee. 1983. Expression and regulation of Escherichia coli lacZ gene fusions in mammalian cells. $J$. Mol. Appl. Genet. 2:101-109.

33. Zysow, B.R., G.E. Lindahl, D.P. Wade, B.L. Knight, and R.M. Lawn. 1995. C/T polymorphism in the $5^{\prime}$-untranslated region of the apolipoprotein(a) gene introduces an upstream ATG and reduces in vitro translation. Arterioscler. Arterioscler. Thromb. Vasc. Biol. 15:58-64.

34. Mooser, V., F.P. Mancini, S. Bopp, A. Petho-Schramm, R. Guerra, E. Boerwinkle, H.-J. Muller, and H.H. Hobbs. 1995. Sequence polymorphisms in the apo(a) gene associated with specific levels of Lp(a) in plasma. Hum. Mol. Genet. 4:173-181.

35. Mizokami, A and C. Chang. 1994. Induction of transcription by the 5 '-untranslated region of human androgen receptor mRNA. J. Biol. Chem. 269: 25655-25659.

36. Genest, J., Jr., J.L. Jenner, J.R. McNamara, J.M. Ordovas, S.R. Silberman, P.W. Wilson, and E.J. Schaefer. 1991. Prevalence of lipoprotein (a) [Lp(a)] excess in coronary artery disease. Am. J. Cardiol. 67:1039-1045.

37. Cooke, T., R. Sheahan, D. Foley, M. Reilly, G. D’Arcy, W. Jauch, M. Gibney, G. Gearty, P. Crean, and M. Walsh. 1994. Lipoprotein(a) in restenosis after percutaneous transluminal coronary angioplasty and coronary artery disease. Circulation. 89:1593-1598.

38. Parlavecchia, M., A. Pancaldi, R. Taramelli, P. Valsania, L. Galli, G. Pozza, S. Chierchia, and G. Ruotolo. 1994. Evidence that apolipoprotein(a) phenotype is a risk factor for coronary artery disease in men $<55$ years of age. Am. J. Cardiol. 74:346-351.

39. Maeda, S., A. Abe, M. Seishima, K. Makino, A. Noma, and M. Kawade. 1989. Transient changes of serum lipoprotein(a) as an acute phase protein. Atherosclerosis. 78:145-150

40. Henriksson, P., B. Angelin, and L. Berglund. 1992. Hormonal regulation of serum Lp (a) levels. Opposite effects after estrogen treatment and orchidectomy in males with prostatic carcinoma. J. Clin. Invest. 89:1166-1171. 